\title{
INVESTIGATION OF SEWAGE SLUDGE PREPARATION FOR COMBUSTION PROCESS
}

\author{
Aneta Magdziarz ${ }^{* 1}$, Małgorzata Wilk ${ }^{1}$, Bogdan Kosturkiewicz ${ }^{2}$ \\ ${ }^{1}$ AGH University of Science \& Technology, Faculty of Metals Engineering and Industrial Computer \\ Science, Al. Mickiewicza 30, 30-059 Kraków, Poland \\ ${ }^{2}$ AGH University of Science \& Technology, Faculty of Mechanical Engineering and Robotics, \\ Al. Mickiewicza 30, 30-059 Kraków, Poland
}

\begin{abstract}
Waste disposal is imposed by the European Union under Treaty of Accession concerning waste management order. One of the waste disposal methods is thermal utilisation. The paper presents an investigation of sewage sludge briquettes used as a fuel in combustion process. The research study was carried out on samples taken from the Municipal Wastewater Treatment Plant in Bochnia. Briquettes with lime were formed. The analysis of the elementary chemical composition of municipal sewage sludge, the composition of the ash and thermogravimetric analysis were carried out. The results indicate that the prepared briquettes had sufficient fuel properties.
\end{abstract}

Keywords: sewage sludge, waste management, briquetting, thermal analysis

\section{INTRODUCTION}

In 2008, more than 1100 tons of municipal and industrial sewage sludge were produced according to Polish Sewage Treatment Plan. The Polish Environmental Policy and the objectives of The 2010 National Waste Management Plan (2006), as well as The National Urban Wastewater Treatment Program (2003) suggest that the sewage sludge problem is very important and requires accurate studies (Werle and Wilk, 2010). It is estimated that the quantity of municipal sewage sludge, which is to be produced in Poland between 2010 and 2018, will increase from 612.8 thousand tons to an estimated 706.6 thousand $\mathrm{Mg}$ (The National Waste Management Plan, 2006). Taking into account these requirements some Polish (e.g. University of Science and Technology AGH, Silesian University of Technology in Gliwice, Wrocław University of Technology) and European research groups are interested in solving this problem (e.g. University of Leon, Spain; University of Leeds, UK; and University of Aveiro, Portugal).

The main method of sewage sludge disposal is its storage and agricultural applications. Sewage sludge is deposited in landfill sites dedicated exclusively to this waste material in lagoons or jointly with municipal waste. This structure of sewage-sludge utilisation in Poland is highly unfavourable. The main problems are a high percentage of stored sewage sludge and a lack of installations for its thermal utilisation. Thermal processes can be used to convert large quantities of sewage sludge into useful energy. Processes of thermal utilisation of sludge can be developed at existing installations (heating plants, power plants, or cement plants) or in newly built facilities. Thermal methods of sewage-sludge utilisation should be preceded by dehydration and drying of sludge. A significant reduction in sludge quantity is achieved through digestion. There is a large and pressing need for the development of 
thermal methods for sludge disposal. Thermal processes can significantly reduce the weight and volume of transformed sewage sludge. A high heavy-metal content in sewage sludge effectively reduces the possibility of its agricultural use. The applicability of using thermal methods for sewagesludge disposal is determined by its properties: e.g., heating value and composition. The heating value of raw sludge is about $17 \mathrm{MJ} / \mathrm{kg}$; for activated sludge, about $15 \mathrm{MJ} / \mathrm{kg}$, and for stabilised sludge (digested or lime stabilised about $11 \mathrm{MJ} / \mathrm{kg}$ (The National Urban Wastewater Treatment Program, 2003). It is clear that sewage sludge should be concentrated, (biologically or chemically) stabilised, and dehydrated by filters. To determine the usefulness of sewage sludge for thermal transformation it is necessary to know its basic physical and chemical characteristics (Nadziakiewicz et al., 2007).

There are several thermal technologies available for thermal processing of sewage sludge: monoincineration (multiple-hearth furnace, fluidised bed, smelting and rotary furnaces), co-combustion (with coal, with other fuels, with MSW) and alternative processes (pyrolysis, oil from sludge, gasification, hybrid methods) (Hamilton, 2000; Bień, 2007; Wandrasz and Wandrasz, 2005). The significant property of sewage sludge is its form. There are many papers about thermal technologies concerning sewage sludge, but the problem of its preparation to combustion is not well described. Therefore, the project is focused on methodology of sewage sludge preparation in the form called "briquette" and determination of its mechanical - strength factors. This form is commonly used in applications of wooden biomass combustion. The original solution to the sewage sludge problem is a new technique of briquetting. Sewage sludge can be combusted or co-combusted (Kruczek et al., 2000; Ogada and Werther 1996; Shimizu et al., 2007; Murakami et al., 2009; Solimene et al., 2009; Otero et al., 2002; Stelmach and Wasilewski, 2008). Combustion is a complex phenomenon involving simultaneous heat and mass transfer with a chemical reaction and fluid flow. Combustion of renewable fuels can cause hazards and operating problems e.g. water content, which is a significant and important problem of combustion. Pollutant emissions generated by combustion are particular matter (PM), carbon monoxide (CO), hydrocarbons ( $\mathrm{HC})$, oxides of nitrogen $\left(\mathrm{NO}_{\mathrm{x}}\right)$ and oxides of sulphur $\left(\mathrm{SO}_{\mathrm{x}}\right)$.

The amount of sewage sludge and physical and chemical characteristics is an important problem for the exploiter sewage treatment plant. Sludge treatment processes are in fact more than $30 \%$ of the cost of operating the entire wastewater treatment plant. Until recently, the problem of sludge management has been little observed and appreciated, and it should be noted that according to the National Waste Management Plan, in 2008 on Polish territory the dry weight of sewage sludge produced approximately 567.3 thousand $\mathrm{Mg}$. A significant barrier to its disposal is a high degree of hydration of sludge up to $80 \%$. Municipal sewage sludge is now used for land reclamation, agriculture, cultivation of plants, some of which are converted into heat, and the rest is stored. The latter is the least desirable method of sewage sludge management. According to the National Waste Management Plan of 2008, the total mass of sludge produced in municipal wastewater treatment plants on Polish territory deposited almost 92 thousand $\mathrm{Mg}$ d.m. (16.1\%). Although there was a significant progress compared to the previous years, the issue of waste storage is still being trivialised. Above-mentioned treatment of sewage sludge is the major source of methane, one of the most dangerous greenhouse gases. Therefore, it is necessary to increase the role of all methods of sewage sludge disposal. In 2008 six thousand $\mathrm{Mg}$ d.m. of waste were disposed, which is over four times more than in 2004 (Figure 1).

According to No. 2001/77/EC Directive of the European Parliament of $27^{\text {th }}$ September 2001 concerning the promotion of the electric production from renewable energy sources, (Nadziakiewicz et al., 2007) the percentage of electricity generated from renewable energy sources in Poland, will amount to $7.5 \%$ in the next years (Figure 2). It is also assumed that $4 \%$ of that energy will be produced from biomass, including thermal conversion of municipal waste.

Minimising environmental risks and facilitation of waste transport requires preparation of a special shape of waste. Taking into account the past few years, the Department of Manufacturing Systems AGH has studied a technology of municipal sewage sludge merging (Kosturkiewicz, 2005; Kosturkiewicz and Tora, 2010). The result of this work allowed to carry out the calculation procedures 
for a business plan and energy balance. The municipal sludge from the wastewater treatment plant in Bochnia was investigated. Samples of the sewage sludge were taken from lagoons near the waste water plant. The Municipal Wastewater Treatment Plant in Bochnia removes waste to the Raba river based on the water permit on 23 August 1976 issued by the Regional Office in Tarnów (based on the regulation of the Minister of Environmental Protection, Natural Resources and Forestry on the classification of waters and the conditions of waste water on 5 November 1991). The average parameters of the waste water from the sewage treatment plant in Bochnia are shown in Table 1. The treatment plant in Bochnia takes about 1013.4 thousand $\mathrm{m}^{3}$ of sewage per year.

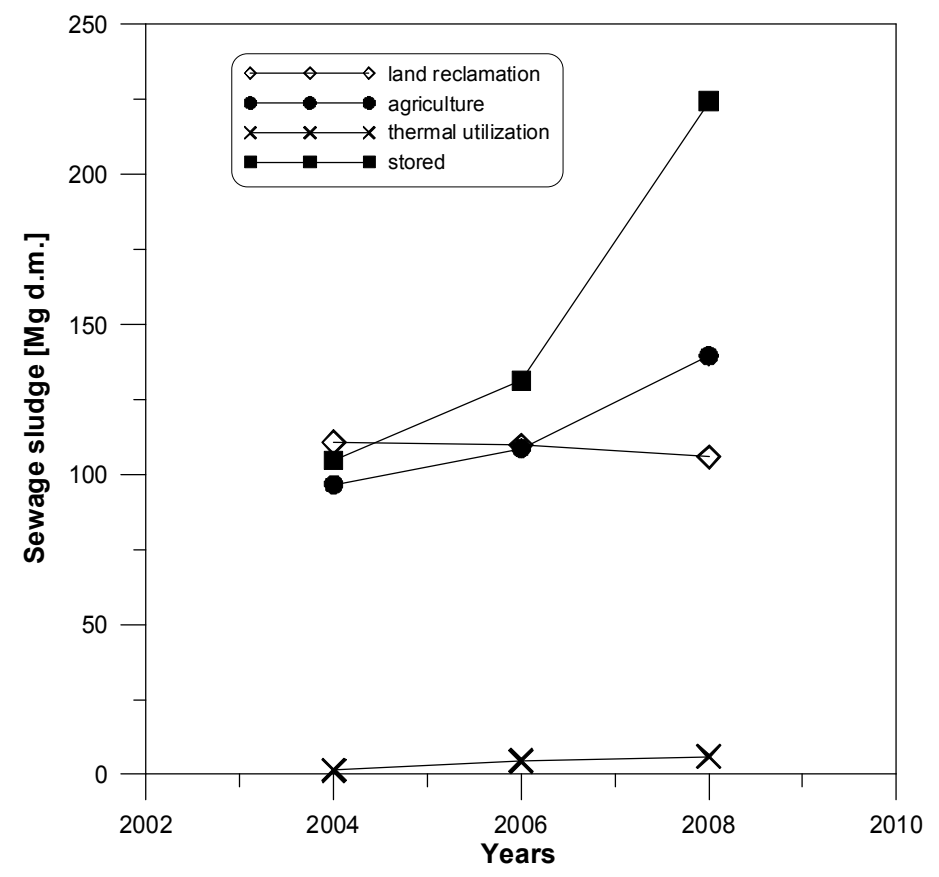

Fig. 1. Method of municipal sewage sludge management in 2004, 2006 and 2008

(Resolution no. 217 by the Council of Ministers, 2010)

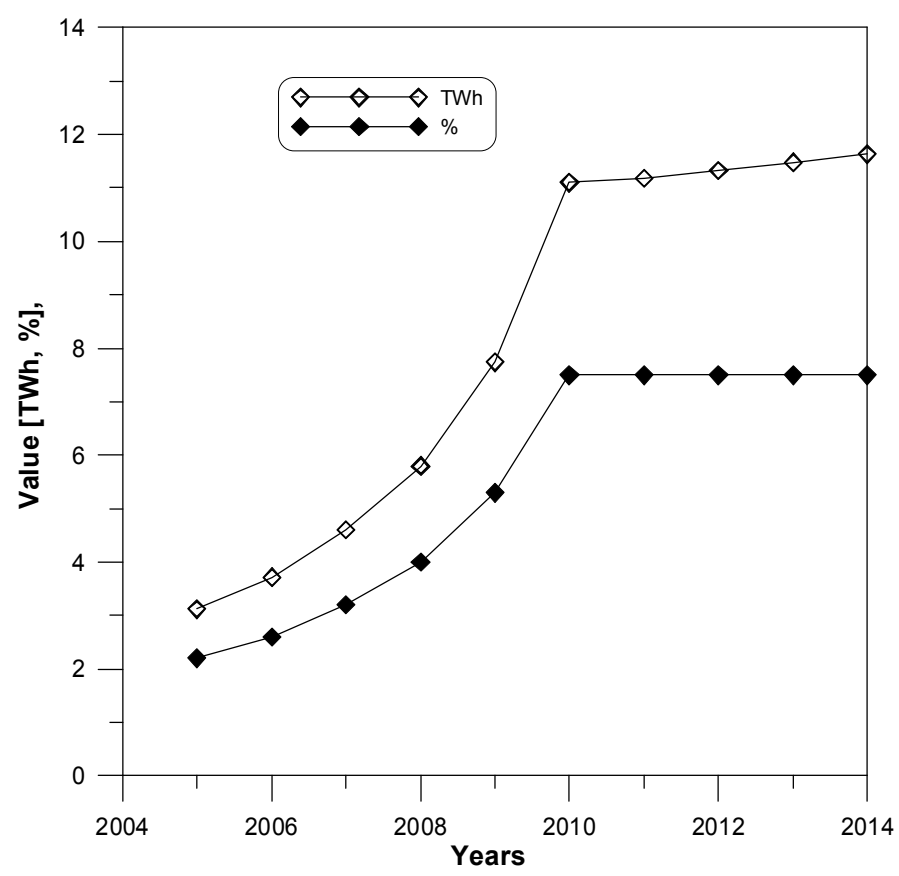

Fig. 2. Electric energy production from renewable energy sources in Poland (Directive 2001/77/EC of the European Parliament and of the European Council, 2001) 
Table 1. The indicators of pollutants in waste water from sewage treatment plant in Bochnia

\begin{tabular}{|c|c|c|}
\hline Pollutant & Concentration & Reduction of pollutants, \% \\
\hline BOD & $4.0 \mathrm{mg} \mathrm{O}_{2} / \mathrm{dm}^{3}$ & 98.75 \\
\hline COD & $33.9 \mathrm{mg} \mathrm{O} / \mathrm{dm}^{3}$ & 94 \\
\hline Suspended matter & $15.2 \mathrm{mg} / \mathrm{dm}^{3}$ & 92 \\
\hline Nitrogen & $27.0 \mathrm{mg} \mathrm{N} / \mathrm{dm}^{3}$ & 65 \\
\hline Phosphorus & $1.0 \mathrm{mg} \mathrm{P} / \mathrm{dm}^{3}$ & 96.15 \\
\hline
\end{tabular}

\section{EXPERIMENTAL}

\subsection{Briquetting process}

The first step of sewage sludge briquetting process was homogenisation of the material composition. The samples were mixed in a mixer with a preheated water jacket. Taking into account the limitation of heat demand for sludge dewatering and appropriate biostabilization, for better uniting burnt lime was added (10\% mass fraction). Mixing time was determined based according to the amount of material moisture. The moisture value of the tested samples was approximately $23.5 \%$. Thus prepared sample was fed into the hopper located above the zone of gravitational compaction of the roller press LPW 450 , which is equipped with forming rings for briquetting process without the parting plane in the shape of a saddle. It is known that the "saddle" shape of the working surface of the rollers allows high pressure units in the briquetting process. That kind of roller press is adequate for uniting difficult materials to briquetting. Tests were carried out in the laboratory set presented in Figure 3. The amount of fine-grained material was $5 \div 7 \mathrm{~kg}$. The sample was united at $0.1 \div 0.4 \mathrm{~m} / \mathrm{s}$ of tangential velocity corresponding to the rotational speed of $4.24 \div 16.99 \mathrm{r} / \mathrm{min}$. The initial value of the interspace between the rolls during briquetting process was $d \sim 1.0 \mathrm{~mm}$.

\subsection{Sewage sludge briquette analysis}

A briquette of sewage sludge was analysed to determine its main properties. These properties include moisture content, heating value, chemical composition and mechanical properties. Volatile matter, ash and moisture were tested in accordance with PN-G-04511:1980, PN-G-04512:1980, PN-G-04516:1981 standards (Polish codes).

\subsection{Thermogravimertric analysis}

Thermogravimetric analysis is one of the instrumental methods used to analyse sewage sludge (Folgueras et al., 2003; Nowicki et al., 2008; Otero et al., 2002). In the present study thermogravimetry (TG) and differential thermal analysis (DTA) were carried out on the tested sample. Before the experiment the calibration of sample holder (sensor system, TG-DTA) has been done and the base line for the studied temperature program has been prepared. The temperature measurements in the experimental apparatus are the most important factor and their accuracy has to be determined. Any changes in the apparatus connected with long-time drift of electronic amplifiers and the aging process of thermocouples can affected the accuracy of temperature measurements. The dynamics of these 
changes are primarily dependent on the number of measurements and the measurement conditions. Those deviations which are assumed to be constant in a measurement are eliminated with temperature calibration. Therefore, the calibration materials for which the transformation temperatures are known with sufficient accuracy must be measured in an experimental run independent of the actual measurement and then saved as the calibration curve. Magnetic features of some substances (e.g. Al, $\mathrm{Bi}, \mathrm{Sn}, \mathrm{Ni}, \mathrm{Fe}$ ) change reproducibly their magnetic features at defined temperatures and due to this fact they can therefore be used for temperature calibration. The changes in the magnetic characteristics of selected substances at defined temperatures (Curie points) are used for the temperature calibration of thermobalances.

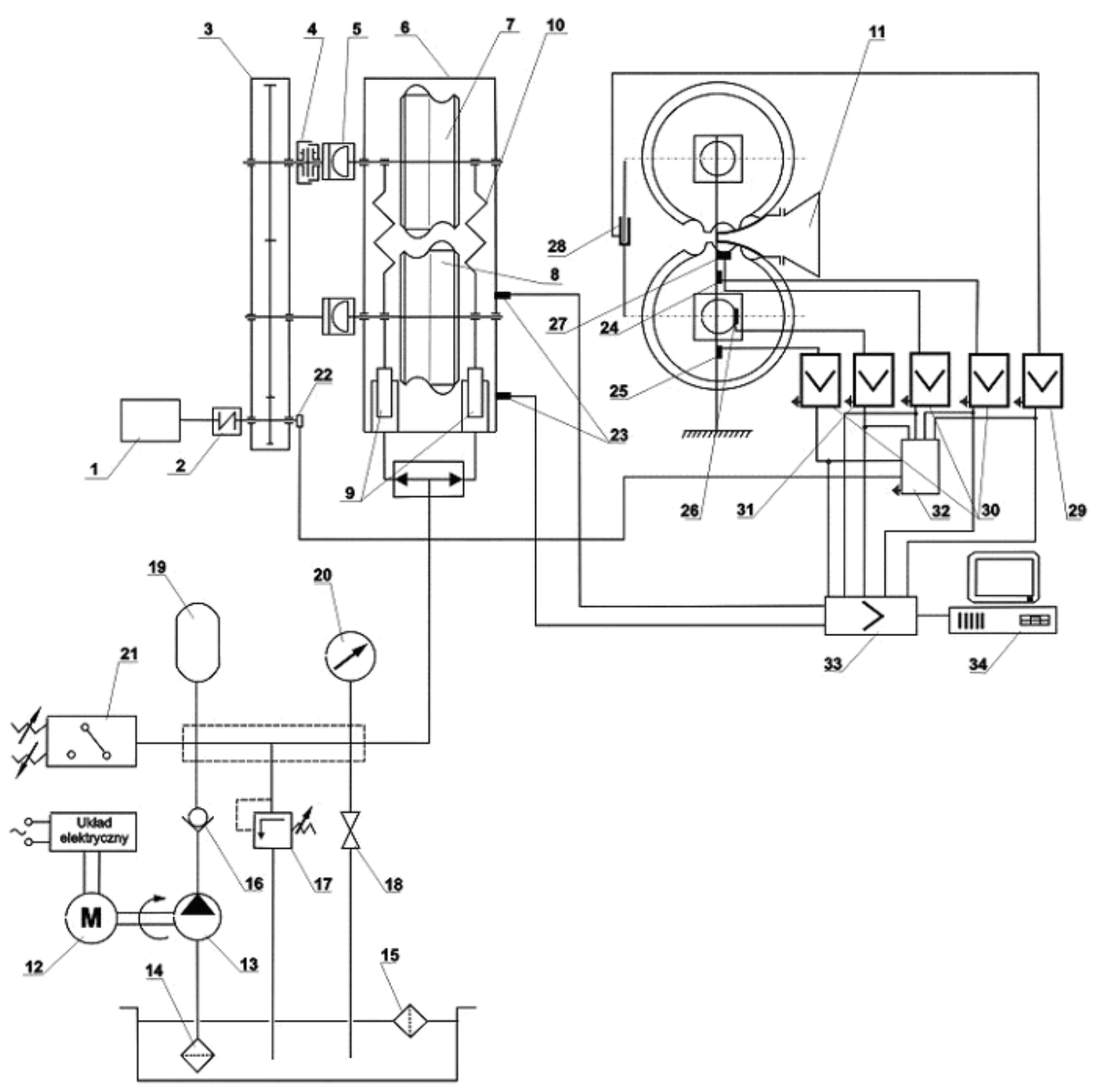

Fig. 3. Diagram of laboratory roll press LPW 450 with measurements system,

1 - gear-motor, 2 - flexible coupling, 3 - toothed rolls squirrel cage, 4 - friction clutch, 5 - Oldhama coupling, 6 - frame, 7 - fixed forming roll, 8 - shifting forming roll, 9 - ram servo-motor, 10 - springy or spacer element, 11 - gravitational hopper, 12 - electric motor, 13 - pump, 14 - suction filter, 15 - strainer filter, 16 - check valve, 17 - overflow valve, 18 - cut-off valve, 19 -gas accumulator, 20 - manometer, 21 - pressure control system, 22 measuring race of output shaft rotational speed of toothed squirrel cage, 23 - vibration sensors, 24 - measuring race of force loading the spacer element, 25 - measuring race of shifting roll pressure force, 26 - measuring race of torque moment on the on the shifting forming roll shaft, 27 - measuring race of pressure in the forming cavity, 28 - measuring race of shifting roll travel, 29 -amplifier PE102, 30 - amplifier MGT-232, 31 - amplifier KMN602, 32 - recorder, 33 - card DAQ-700 (National Instruments), 34 - computer (notebook) 
For the studied experiment, the temperature calibration has been done for In, Al, Bi, Sn. The pure metals (ideal beads of approximately $1 \mathrm{~mm}$ in diameter) were heated beyond their melting points. Each calibration material was heated three times over the melting effect to be observed. The three required heating cycles were carried out on the same sample within the temperature program (for recording the melting peaks a data acquisition rate of at least 6 to 8 points $/ K$ should be used). The temperature calibration was carried out under exactly the same conditions as the corresponding sample's measurements (the range of temperature, atmosphere, heating rate, etc.). The obtained data of the temperature calibration allowed to prepare the base line for the studied temperature program. Having obtained the base line the thermal analysis of studied samples was conducted.

During the investigation of a sample the proceeding effects have to be interpreted and the consistency of the sample must be considered. Good thermal contact between the sample and heat-flux sensor is an indispensable requirement for optimum results. The studied sample was representative for the studied material and it was prepared in a powder form. The obtained data were considered repeatable by taking into account the measurement errors. Each sample was evenly distributed at the bottom of the aluminium crucible $\left(\mathrm{Al}_{2} \mathrm{O}_{3}\right)$ in the NETZSCH STA Jupiter 449F3. $31 \mathrm{mg}$ of the sample was heated from an ambient temperature up to $1010^{\circ} \mathrm{C}$ at a constant rate of $10^{\circ} \mathrm{C} / \mathrm{min}$ in $40 \mathrm{ml} / \mathrm{min}$ flow of synthetic air. The measurements for each sample have to be done under exactly the same condition including e.g. the range of temperature, atmosphere, heating rate, etc. to determine the most repeatable and precise results.

\section{RESULTS AND DISCUSSION}

After briquetting process of sewage sludge with lime addition, briquettes were obtained in the shape presented in Figure 4. The following properties were determined for the obtained briquettes: the density $\left(\rho=1.54 \div 1.71 \mathrm{~g} / \mathrm{cm}^{3}\right)$, drop strength $(>99 \%)$, compressive strength $\left(D_{168}=500 \div 1100 \mathrm{~N}\right)$, and unit pressure $(p=18 \div 51 \mathrm{MPa})$.

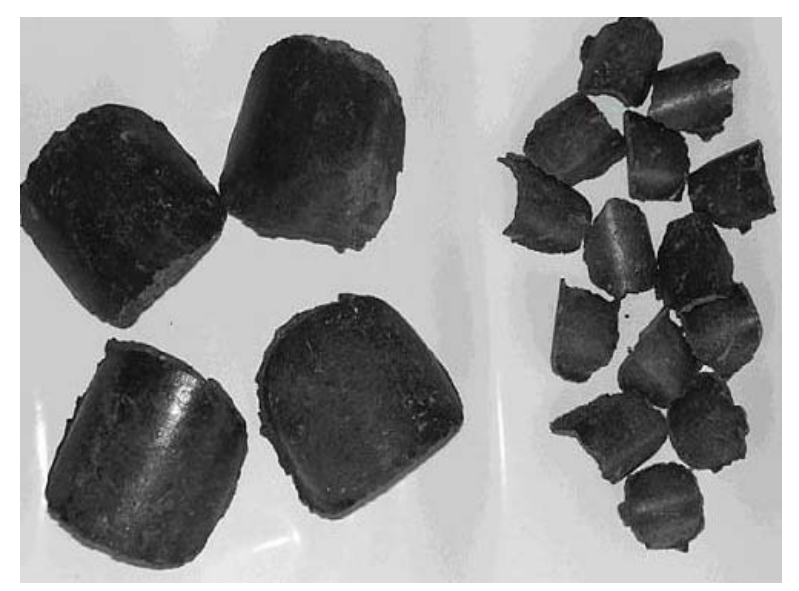

Fig. 4. Photo of united sewage sludge

The obtained briquettes were characterised by a high drop of strength coefficient after the test had been made and after 168 hours had passed (Figure 5). The values of compressive strength were also regarded as significantly high. Figure 6 presents dependencies between strength coefficients via rotational speed of the rollers.

Compressive strength tests of the briquettes were carried out on the press, equipped with a ZWICK 1120 with the pressure from 0 to $2000 \mathrm{~N}$. The briquettes were squeezed between two parallel planes with a velocity $v=0.001 \mathrm{~m} / \mathrm{s}$, and the direction of force was perpendicular to these planes. The strength 
tests were performed after $168 \mathrm{~h}$ of ageing in order to minimise the impact of weather conditions (humidity, temperature) on the value of the obtained results. Discharges of the briquettes were made in a series of 10 with a height of $2 \mathrm{~m}$ on a steel plate $60 \mathrm{~mm}$ thick. These tests were repeated three times, each time by means of a sieve with a mesh size $18 \times 18 \mathrm{~mm}$. The sieve size was specified as $2 / 3$ of the calculated average of the two maximum dimensions of a briquette, measured in mutually perpendicular directions.

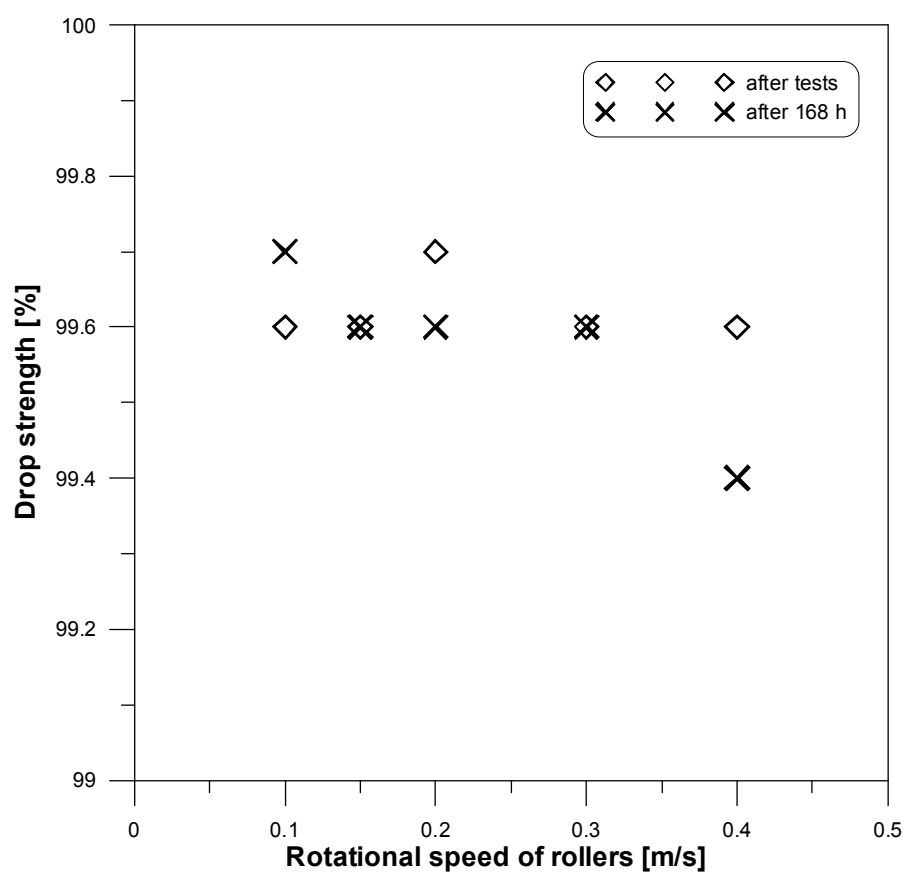

Fig. 5. Drop in strength after 168 hours via rotational speed of rollers

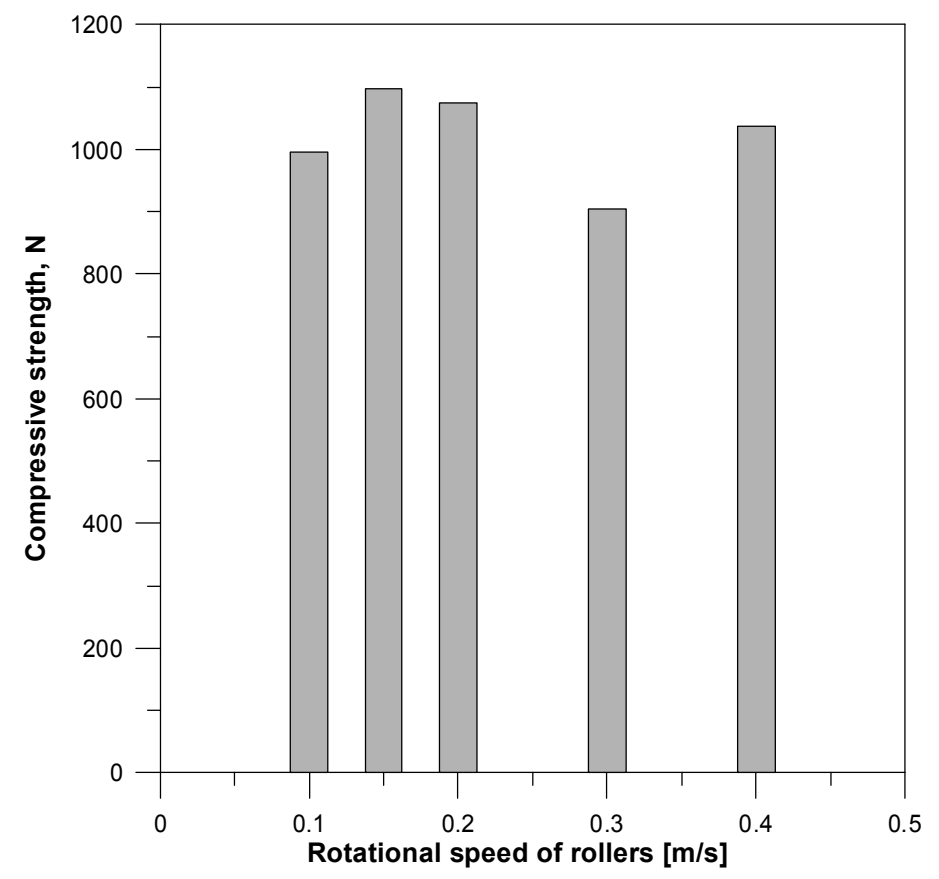

Fig. 6. Compressive strength after 168 hours via rotational speed of rollers

The elementary composition of sewage sludge and the contents of trace elements and inorganic compounds are very important factors that should also be investigated apart from physical properties of the studied briquettes. Municipal sewage sludge from waste water treatment plant contains a lot of 
organic matter, some heavy metals and pathogenic organisms. The chemistry of sewage sludge has a high diversity and variability caused by biochemical changes occurring in time. To determine the usefulness of sewage sludge for thermal transformation it is necessary to know its basic physical and chemical characteristics. The chemical composition of the studied material and ash composition are presented in Tables 2 and 3. The main combustible component in the tested material is carbon. The total content of organic matter is $43.7 \%$. Comparing with the literature (Nadziakiewicz et al., 2007) the studied sludge contains a relatively large amount of organic matter, which suggests that it has adequate fuel properties. Sewage sludge also contains components that are present in municipal waste, and thus trace metals whose levels may be higher than those in raw waste. Zinc was the most common of the trace elements but copper and lead were also detected. It should be noted that in the investigated sludge the amount of harmful heavy metals $(\mathrm{Pb}, \mathrm{Cd}, \mathrm{Hg})$ is low (Hamilton, 2000; Otero et al., 2002). It was concluded that considering the level of harmful substances per unit of produced energy, sludge can be thermally utilised.

Table 2. Chemical analysis of sewage sludge briquette

\begin{tabular}{|c|c|}
\hline Denotation & Value \\
\hline Organic matter, \% d.m. & 43.7 \\
\hline Nitrogen, \% d.m. & 2.9 \\
\hline Phosphorus, \% d.m. & 3.3 \\
\hline Calcium, \% d.m. & 2.4 \\
\hline Magnesium, \% d.m. & 0.33 \\
\hline Lead, mg/kg d.m. & 75.6 \\
\hline Cadmium, mg/kg d.m. & 3.6 \\
\hline Mercury, mg/kg d.m. & 0.6 \\
\hline Nickel, mg/ kg d.m. & 22.8 \\
\hline Zinc, mg/kg d.m. & 1183 \\
\hline Copper, mg/kg d.m. & 103 \\
\hline Chromium, mg/kg d.m. & 36.1 \\
\hline
\end{tabular}

Table 3 presents the results of ash composition. The amount of oxides in the ash is quantitatively different. The concentrations of $\mathrm{SiO}_{2}$ and $\mathrm{Al}_{2} \mathrm{O}_{3}$ are the largest, while the concentrations of $\mathrm{CaO}, \mathrm{P}_{2} \mathrm{O}_{5}$ and $\mathrm{Fe}_{2} \mathrm{O}_{3}$ are much lower. Alkali metals, chlorine and sulphur released during combustion can cause corrosion at a high temperature, which is the basic problem of using renewable fuel boilers. Analysis of the corrosivity of the studied sludge allowed to conclude that it causes low-risk of corrosion.

Table 3. Ash chemical composition (\%) of sewage sludge briquette

\begin{tabular}{|c|c|c|c|c|c|c|c|c|}
\hline $\mathrm{SiO}_{2}$ & $\mathrm{CaO}$ & $\mathrm{MgO}$ & $\mathrm{Fe}_{2} \mathrm{O}_{3}$ & $\mathrm{Al}_{2} \mathrm{O}_{3}$ & $\mathrm{P}_{2} \mathrm{O}_{5}$ & $\mathrm{Na}_{2} \mathrm{O}$ & $\mathrm{K}_{2} \mathrm{O}$ & $\mathrm{Cl}^{-}$ \\
\hline 32.93 & 5.56 & 0.98 & 2.24 & 23.41 & 0.42 & 0.73 & 1.75 & 2.32 \\
\hline
\end{tabular}

The content of organic matter in sewage sludge is an indicator of its fuel properties and the possibility of applying it in thermal processes. The lower heating value is dependent on the chemical composition of sewage sludge. Dependence of lower heating value via moisture was determined for the energy balance according to the PNZ15008-04:1993 (Polish codes). 


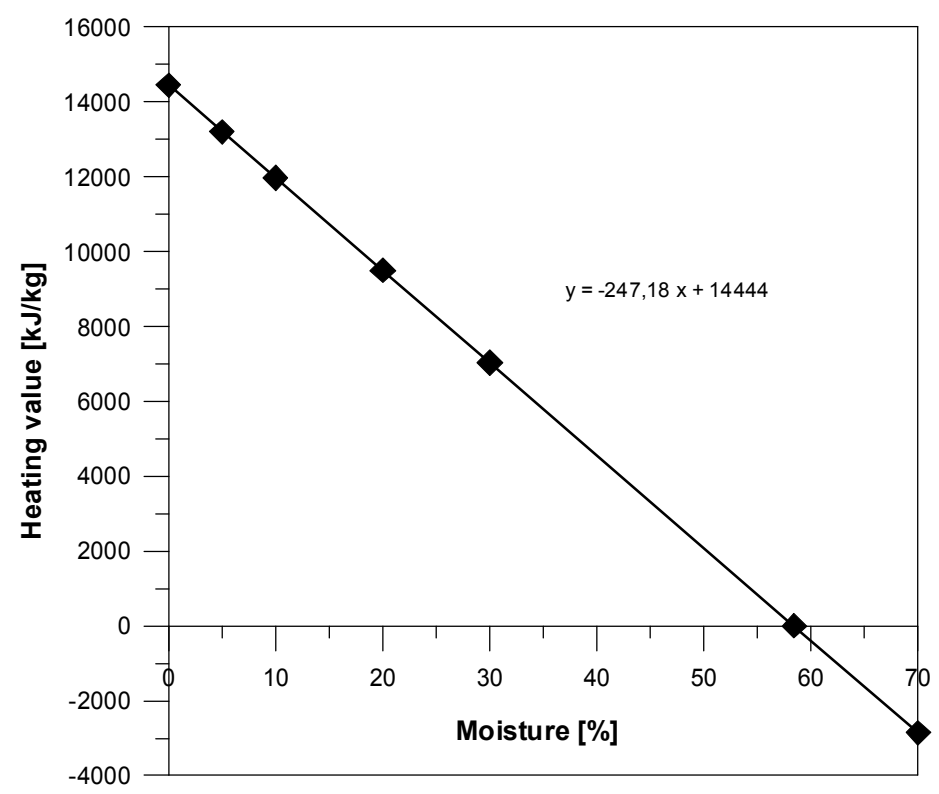

Fig. 7. Lower heating value via moisture of municipal sewage sludge

The briquettes were united with $23.5 \%$ of moisture. The lower heating value for such a condition was determined as $8635 \mathrm{~kJ} / \mathrm{kg}$ (Figure 7). The amount of electric or heat energy from briquetting process can be calculated as follows:

$$
E_{\text {OZE }}=m_{\mathrm{p}} W_{\mathrm{op}}-E_{\mathrm{z}}-E_{t}-3.6 m_{b} Z_{e}[\mathrm{MJ}]
$$

where:

$m_{\mathrm{p}} \quad$ - mass of burned sewage sludge in a manufacturing unit, $\mathrm{Mg}$,

$W_{o p} \quad$ - lower heating value of sewage sludge, $\mathrm{MJ} / \mathrm{Mg}$,

$E_{\mathrm{z}} \quad$ - amount of electric or heat energy for dewatering process, MJ,

$E_{t} \quad$ - amount of electric energy for preparing of mixture to unit the briquette, MJ,

$m_{\mathrm{b}} \quad$ - mass of briquetting material, $\mathrm{Mg}$,

$Z_{\mathrm{e}} \quad$ - energy demand for briquetting process, $\mathrm{kWh} / \mathrm{Mg}$.

Thermogravimetry (TG) and differential thermal analysis (DTA) are techniques largely untried in sludge characterisation. Recently thermal methods have been successfully extended to the study of combustion of sludge similar to those for coal and wood. Figure 8 presents the TG and DTA curves of the studied material. The obtained TG and DTA curves allowed us to analyse the processes of sewage sludge briquette heating.

The TG curve represents the instantaneous weight percentage of the tested sludge in contrast to the initial weight. The TG curve can be divided into three different stages. The first stage from ambient temperature at the beginning of the test to about $200^{\circ} \mathrm{C}$ presents a slight decay of the tested sample's weight due to drying and release of some light volatiles. The weight loss of the tested material is less than $7 \%$. The second stage began at $200^{\circ} \mathrm{C}$ and ended at about $820^{\circ} \mathrm{C}$. The significant drop of weight was probably caused by thermal decomposition of carbonaceous material. Once the temperature rose higher than $820^{\circ} \mathrm{C}$ no weight loss was observed and the process was finished. On the base of the TG curve it is assumed that a large amount of ash is detected (to 40\%). Such a large amount of ash appearing during the process is not desirable, because of problems concerning the operating conditions. The obtained DTA curve made it possible to analyse the thermal effects. The obtained peaks presented in Figure 8 correspond with exothermal effects. Thus, three exothermal effects with a temperature maximum of 357,483 and $705^{\circ} \mathrm{C}$ were determined. The thermal effects observed as DTA peaks are connected with thermal decomposition of organic matter. The gaseous products generated during the 
sewage sludge material heating have not been investigated. However, information about the gaseous products could have helped to better explain the process.

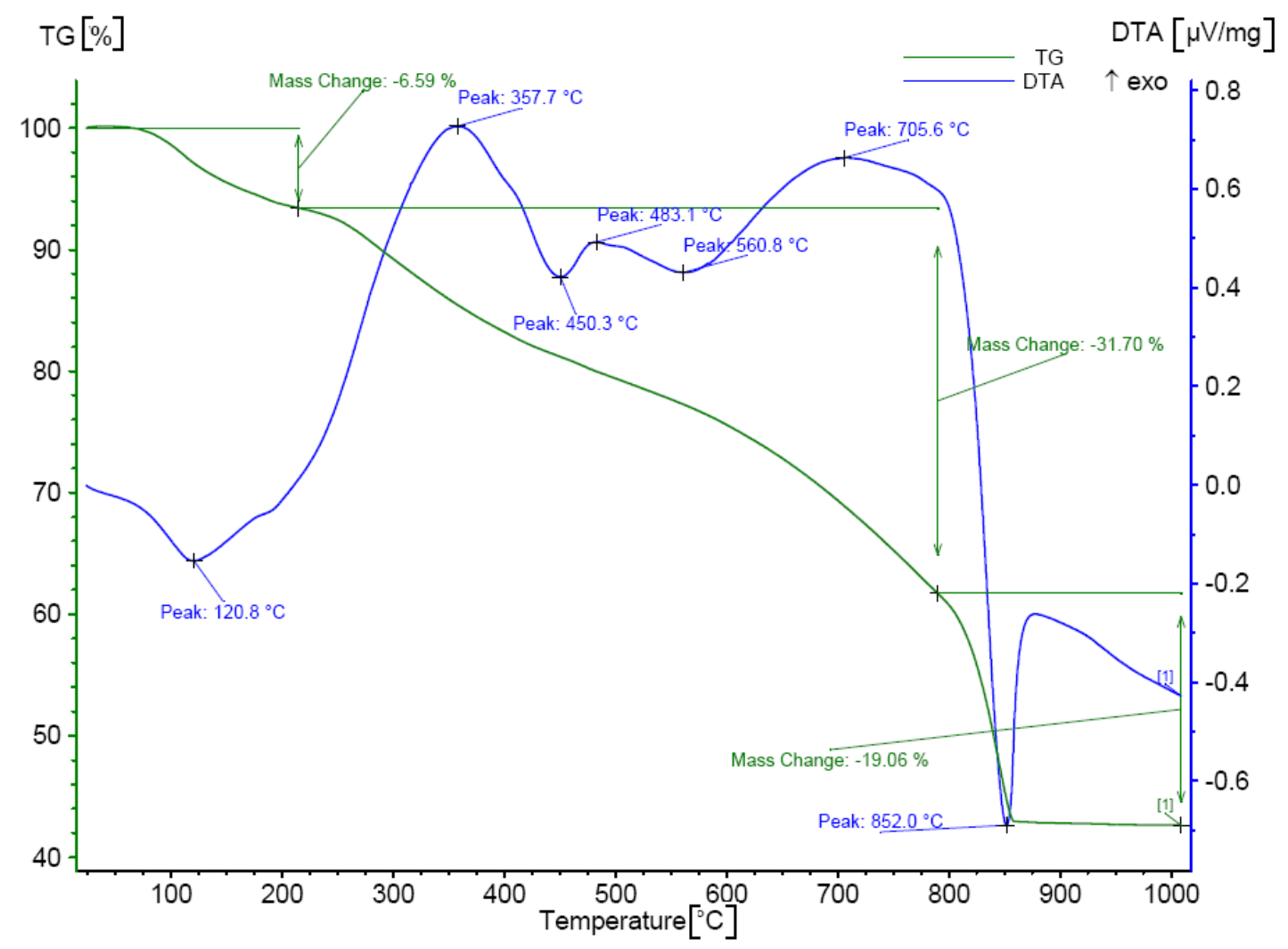

Fig. 8. TG and DTA curves for tested sewage sludge

\section{CONCLUSIONS}

From the results obtained in this study, it can be concluded that the sewage sludge from the Municipal Wastewater Treatment Plant in Bochnia can be formed as briquettes. This study indicated that the briquettes of municipal sewage sludge with lime have good mechanical properties. The designed laboratory roll press LPW 450 fulfilled assumptions and can be used to form sewage sludge briquettes. The investigations show that the briquettes formed from a mixture of sewage sludge and lime have adequate properties for thermal utilisation. The prepared "fuel" was characterised by a relatively high calorific value (about $8.6 \mathrm{MJ} / \mathrm{kg}$ ) at $23.5 \%$ moisture content. However, the thermogravimetric analysis indicated a large amount of ash up to $40 \%$, which is undesirable in combustion process. Taking into account the waste disposal problems which have to be solved in the next two years the presented method of briquetting sewage sludge is the first step to its thermal utilisation.

The financial support by the Polish Ministry of Science and Higher Education - grant No 0231/T02/2010/70 "Iuventus Plus" is acknowledged.

Part of the work was supported by the Polish Ministry of Science and Higher Education (D.S.AGH 11.11.130.886).

\section{REFERENCES}

Bień J.B., 2007. Sewage sludge. Theory and practice. Wydawnictwo Politechniki Częstochowskiej, Częstochowa (in Polish). 
Directive 2001/77/EC of the European Parliament and of the Council of 27 September 2001 on the promotion of electricity produced from renewable energy sources in the internal electricity market.

Folgueras M.B., Diaz R.M., Xiberta J., Prieto I., 2003. Thermogravimetric analysis of the co-combustion of coal and sewage sludge. Fuel, 82, 2051-2055. DOI:10.1016/S0016-2361(03)00161-3.

Hamilton C.J., 2000. Gasification as an innovative method of sewage-sludge disposal. Water Environ. J., 14, 8993. DOI: 10.1111/j.1747-6593.2000.tb00232.x.

Kosturkiewicz B., 2005. The study of the use of roller presses for sewage sludge management. Ochrona Powietrza i Problemy Odpadów, 4, 228, 138-145 (in Polish).

Kosturkiewicz B., Tora B., 2010. Proposition of energetic utilization of sewage sludge from Bochnia. Waste Forum, 4, 385-388.

Kruczek H., Hajduk A., Grochowski A. 2000. $\mathrm{NO}_{\mathrm{x}}$ and $\mathrm{SO}_{2}$ emission from co-combustion of brown coal with biomass. Scientific Papers of the Institute of Engineering and Fluid Mechanics of the Technical University of Wroclaw. Conferences, 56 (10), 21-30.

Murakami T., Suzuki Y., Nagasawa H., Yamamoto T., Koseki T., Hirose H., Okamoto S., 2009. Combustion characteristic of sewage sludge in an incineration plant for energy recovery. Fuel Process. Technol., 90, 778-83. DOI:10.1016/fuproc2009.03.003.

Nadziakiewicz J., Wacławiak K., Stelmach S. 2007. Thermal processes for waste treatment. Wyd. Politechniki Śląskiej. Gliwice (in Polish).

Nowicki L., Stolarek P., Olewski T., Bedyk T., Ledakowicz S., 2008. Mechanism and kinetics of sewage sludge pyrolysis by thermogravimetry and mass spectrometry analysis. Chem. Process Eng., 29, 813-825.

Ogada T., Werther J., 1996. Combustion characteristics of wet sludge in a fluidised bed. Release and combustion of the volatiles. Fuel, 75, 5, 617-626. DOI: 10.1016/0016-2361(95)00280-4.

Otero M., Calvo L.F., Estrada B., Garcia A.I., Moran A., 2002. Thermogravimetry as a technique for establishing the stabilization progress of sludge from wastewater treatment plants. Thermochimica Acta, 389, 121-132. DOI: 10.1016/S0040-6031(01)00856-5.

Otero M., Diaz C., Calvo L.F., Garcia A.I., Moran A., 2002. Analysis of the co-combustion of sewage sludge and coal by TG-MS, Biomass \& Bioenergy, 22, 319-329. DOI: 10.1016/S0961-9534(02)00012-0.

Shimizu T., Toyono M., Ohsawa H., 2007. Emission of $\mathrm{NO}_{\mathrm{x}}$ and $\mathrm{N}_{2} \mathrm{O}$ during via co-combustion of dried sewage sludge with coal in a bubbling fluidized bed combustor, Fuel, 86, 957-64. DOI:10.1016/j.fuel.2006.10.001.

Solimene R., Urciuolo M., Cammmarota A., Chirone R., Salationo P., Damonte G., Donati C., Puglisi G., 2009. Devolatilization and ash comminution of two different sewage sludges under fluidized bed combustion conditions. Mediterranean Combustion Symposium. Ajaccio, France, June 7-11 2009.

Stelmach S., Wasilewski R., 2008. Co-combustion of dried sewage sludge and coal in a pulverized coal boiler. J. Mater. Cycles Waste Manag., 10, 110-115. DOI: 10.1007/s10163-007-0206-9.

The National Urban Wastewater Treatment Program, 2003. The Council of Ministers, Resolution No. 219, 29.10.2002, Official Journal - Monitor Polski, 11, 159 (in Polish).

The National Wastes Management Plan 2014, 2010. The Council of Ministers, Republic of Poland, Resolution No. 217, 24.12.2010, Official Journal - Monitor Polski, 101, 1183 (in Polish).

The 2010 National Waste Management Plan. Poland, 2006. The Council of Ministers, Resolution No. 233,29 December 2006, available at: http://www.mos.gov.pl/g2/big/2009_06/e97e2a07ce29b48c19f462f83a6bf1a9.pdf

Wandrasz J.W., Wandrasz A.J., 2006. Formed fuels. Wydawnictwo Seidel-Przywecki, Warszawa (in Polish).

Werle S., Wilk R.K., 2010. A review of methods for the thermal utilization of sewage sludge: The Polish perspective. Renew. Energy, 35, 1914-1919. DOI:10.1016/j.renene.2010.01.019. 